\title{
The potential role of mobile phones in the spread of bacterial infections
}

\author{
Kabir O. Akinyemi ${ }^{1}$, Audu D. Atapu ${ }^{1}$, Olabisi O. Adetona ${ }^{1}$ \\ and Akitoye O. Coker ${ }^{2}$ \\ ${ }^{1}$ Department of Microbiology, Lagos State University, Ojo PMB 1087, Apapa, Lagos, Nigeria, \\ ${ }^{2}$ Department of Medical Microbiology and Parasitology, College of Medicine, University of Lagos, Idi-Araba, PMB 12003, Lagos
}

\begin{abstract}
Background: Mobile phones are indispensable accessories both professionally and socially but they are frequently used in environments of high bacteria presence. This study determined the potential role of mobile phones in the dissemination of diseases.

Methodology: Specifically, 400 swab samples from mobile phones were collected and divided into groups categorized by the owners of the phones as follows: Group A was comprised of 100 food vendors; Group B, 104 lecturers/students; Group C, 106 public servants; and Group D, 90 health workers. Samples were cultured and the resulting isolates were identified and subjected to antimicrobial susceptibility tests by standard procedures.

Results: The results revealed a high percentage $(62.0 \%)$ of bacterial contamination. Mobile phones in Group A had the highest rate of contamination (92; 37\%), followed by Group B (76; 30.6\%), Group C (42; 16.9\%), and Group D (38; 15.3\%). Coagulase negative Staphylococcus (CNS) was the most prevalent bacterial agent from mobile phones in Group A (50.1\%) and least from phones in Group D (26.3), followed by $S$. aureus. Other bacterial agents identified were Enterococcus feacalis, Pseudomonas aeruginosa, Escherichia coli, and Klebsiella spp. There was no statistical significance difference $(\mathrm{P}<0.05)$ in the occurrence of S. aureus, the most frequently identified pathogenic bacterial agent isolated from the mobile phones in the study groups. Fluoroquinolones and third-generation cephalosporin were found to be effective against most isolates.

Conclusion: Mobile phones may serve as vehicles of transmission of both hospital and community-acquired bacterial diseases. Strict adherence to infection control, such as hand washing, is advocated.
\end{abstract}

Key words: Mobile phone, bacteria, disease, transmission, nosocomial

J Infect Dev Ctries 2009; 3(8):628-632.

Received 12 March 2009 - Accepted 5 August 2009

Copyright $\odot 2009$ Akinyemi et al. This is an open-access article distributed under the Creative Commons Attribution License, which permits unrestricted use, distribution, and reproduction in any medium, provided the original work is properly cited.

\section{Introduction}

The global system for mobile telecommunication (GSM) was established in 1982 in Europe with a view of providing and improving communication network. Today, mobile phones have become one of the most indispensable accessories of professional and social life. Although they are usually stored in bags or pockets, mobile phones are handled frequently and held close to the face $[1,2]$.

The use of cell phones often occurs in hospitals, by patients, visitors and health care workers, and this is one environment where hospital-associated infection is most prevalent. Also, travellers who go to low-income countries where potable water and good sanitation are limited are exposed to the risk of contracting infections because these individuals carry phones, and the potential of such accessories in the spread of bacteria infection is not yet clear $[3,4]$.
Enteric pathogens are the most frequent cause of diarrhoea and account for an annual mortality rate of about five million people worldwide [5]. The first study of bacterial contamination of mobile phones was conducted in a teaching hospital in Turkey with a bed capacity of 200 and one intensive care unit [6]. One-fifth of the cellular telephones examined in a study conducted in New York were found to harbor pathogenic microorganisms [7].

In Nigeria, there has been an increase in the use of mobile phones among the general population, and the use of phones is common in certain areas of the environment where the percentage presence of bacteria is likely high, such as in hospitals, in animal slaughter areas, and in toilets. Therefore, the present study was conducted to determine whether mobile phones could play a role in the spread of bacterial pathogens and to proffer possible control or 
preventive measures that could be instituted to avoid this likely vehicle of infection

\section{Methods and Materials}

Subjects

A total of 400 mobile phones randomly sampled from the users of these phones were examined. The phones were obtained from the following study groups for three months between July and September, 2007: Group A, 100 food vendors; Group B, 104 lecturers/students; Group C, 106 public servants; and Group D, 90 health workers. The users of these mobile phones were adult volunteers. The concept of the study was explained to all subjects and their consent sought.

\section{Sample collection and bacteriological analysis}

The samples were collected aseptically using damp cotton swaps by rotating the swabs on the keys, mouthpiece, and ear-piece of the mobile phone. Samples were first inoculated into brain heart infusion (BHI) as transport medium and incubated aerobically at $37^{\circ} \mathrm{C}$ for 24 hours. Further subcultures were on $5 \%$ sheep blood agar and eosin methyleneblue agar plates and were incubated aerobically at $37^{\circ} \mathrm{C}$ for 24 hours. Plates were observed for growth and colonial morphology of the isolates. The isolates were gram stained, and were further tested for the presence of catalase and oxidase enzymes. Grampositive catalase-positive cocci were tested for mannitol utilisation and coagulase development. Catalase-negative gram-positive cocci were tested using API Strep (Biometieux, marcy L'etoil, France), and Gram-negative bacilli were tested using API $32 \mathrm{E}$ (Biomerieux, marcy L'etoil, France). All Staphylococcus aureus and Enterococcus feacalis strains were screened for methicillin and vancomycin resistance.

\section{Antimicrobial susceptibility testing}

Sensitivity of isolates to antibiotics was determined on Muller-Hinton agar by the disk diffusion method [8]. Briefly, five colonies of each of the isolates were emulsified in Bijou bottles containing $3 \mathrm{ml}$ normal saline. A cotton swab was dipped into the suspension and the swab turned against the side of the bottles to remove excess fluid. The inoculated swab was then streaked across the surface of the Muller-Hinton agar. The inoculated plates were allowed to dry for 4-5 minutes before each of the following antibiotic disks (Oxoid, U.K) was placed on the plates: Ceftriaxone $(30 \mu \mathrm{g})$,
Ofloxacin $(5 \mu \mathrm{g})$, Chloramphenicol $(30 \mu \mathrm{g})$, Erythromycin $(15 \mu \mathrm{g})$, Gentamycin $(10 \mu \mathrm{g})$ Nitroforantoin $(300 \mu \mathrm{g})$, Tetracycline $(30 \mu \mathrm{g})$, Cotrimoxazole $(5 \mu \mathrm{g})$, Amoxycillin $(10 \mu \mathrm{g})$, Pefloxacin $(5 \mu \mathrm{g})$, Cipfloxacin $(5 \mu \mathrm{g})$ Augmentin $12.5 \mu \mathrm{g})$ and Streptromycin $(1 \mu \mathrm{g})$. The plates were incubated aerobically at $37^{\circ} \mathrm{C}$ for $18-24$ hours. The diameters of the zones of inhibition were measured with a ruler and compared with a zone-interpretation chart [8]. Escherichia coli ATCC 25922 was used as the control.

\section{Results}

Out of 400 samples evaluated, a bacterial agent was observed in 248 and none from 152 samples. The results of this study showed a high percentage (62.0\%) of bacterial contamination of mobile phones. Out of the four groups (A-D) studied, Group A (marketers and food vendors) had the highest rate of contamination $(92 ; 37 \%)$. Group B (lecturers and students) had the next highest $(72 ; 30.6 \%)$; and Group C (Public servants) $(42 ; 16.9 \%)$ the next highest. Group D (hospital workers) had the lowest rate of contamination (38; 15.3\%) (Table 1). Specifically, coagulase negative Staphylococcus (CNS) strains, the most frequently encountered bacterial agent, were isolated from the mobile phones of $50.1 \%, 39.5 \%, 47.5 \%$ and $26.3 \%$ of Groups A, B $\mathrm{C}$ and $\mathrm{D}$ respectively. These results were followed closely by $S$. aureus strains which were found in $34.7 \%, 23.7 \%, 28.8 \%$ and $36.8 \%$ of Groups A, B, and $\mathrm{C}$ in that order. Other bacterial pathogens isolated from the mobile phones of all four groups in this study include Enterococcus feacalis, Escherichia coli, and Klebsiella spp. Pseudomonas aeruginosa strains were isolated only from the phones of Group D (Table 1). Antimicrobial susceptibility tests for the isolates revealed that ciprofloxacin, ofloxacin, and perfloxacin were found to inhibit $80.7 \%, 81.5 \%$ and $82.3 \%$ of the bacterial agents isolated, respectively. Ceftriaxone inhibited $79.0 \%$ of the organisms, while amoxacillin was $100 \%$ effective against $P$. aeruginosa and moderately active against Klebsiella species (Table 2).

\section{Discussion}

In this study, $62 \%$ of 400 mobile phones from all the study groups were found to be contaminated by 
Table 1. Bacterial agents identified in the study

\begin{tabular}{|c|c|c|c|c|c|c|c|c|c|}
\hline \multirow[b]{2}{*}{ 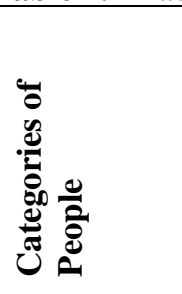 } & \multirow[b]{2}{*}{ 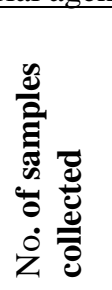 } & \multirow[b]{2}{*}{ 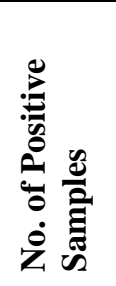 } & \multicolumn{7}{|c|}{ Bacterial agents isolated } \\
\hline & & & $\begin{array}{l}\tilde{\Xi} \\
\stackrel{5}{\Xi} \\
\dot{\Xi}\end{array}$ & 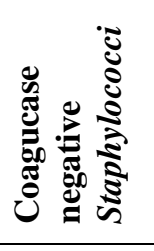 & 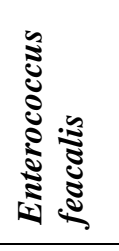 & $\begin{array}{l}\dot{8} \\
\dot{8}\end{array}$ & 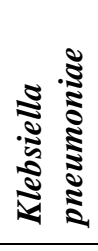 & 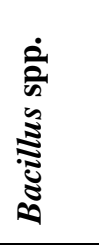 & 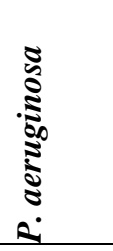 \\
\hline $\begin{array}{l}\text { Marketers / } \\
\text { Food } \\
\text { vendors } \\
\text { Group A }\end{array}$ & 100 & 92 & $\begin{array}{c}32 \\
(34.7)\end{array}$ & $\begin{array}{c}46 \\
(50.1)\end{array}$ & $\begin{array}{c}2 \\
(2.2)\end{array}$ & $\begin{array}{c}8 \\
(8.6)\end{array}$ & $\begin{array}{c}2 \\
(2.2)\end{array}$ & $\begin{array}{c}2 \\
(2.2)\end{array}$ & - \\
\hline $\begin{array}{l}\text { Lecturer } \\
\text { /Students } \\
\text { Group B }\end{array}$ & 104 & 76 & $\begin{array}{c}18 \\
(23.7)\end{array}$ & $\begin{array}{c}30 \\
(39.5)\end{array}$ & $\begin{array}{c}10 \\
(13.2)\end{array}$ & $\begin{array}{c}8 \\
(0.5)\end{array}$ & $\begin{array}{c}6 \\
(7.9)\end{array}$ & $\begin{array}{c}2 \\
(2.6)\end{array}$ & $\begin{array}{c}2 \\
(2.6)\end{array}$ \\
\hline $\begin{array}{l}\text { Public } \\
\text { Servants } \\
\text { Group C }\end{array}$ & 106 & 42 & $\begin{array}{c}12 \\
(28.8)\end{array}$ & $\begin{array}{c}20 \\
(47.5)\end{array}$ & $\begin{array}{c}4 \\
(9.5)\end{array}$ & $\begin{array}{c}4 \\
(9.5)\end{array}$ & $\begin{array}{c}2 \\
(4.7)\end{array}$ & - & - \\
\hline $\begin{array}{l}\text { Hospital } \\
\text { workers } \\
\text { group D }\end{array}$ & 90 & 38 & $\begin{array}{c}14 \\
(36.8)\end{array}$ & $\begin{array}{c}10 \\
(26.3)\end{array}$ & $\begin{array}{c}4 \\
(10.5)\end{array}$ & $\begin{array}{c}2 \\
(5.2)\end{array}$ & $\begin{array}{c}2 \\
(5.2)\end{array}$ & $\begin{array}{c}2 \\
(5.2)\end{array}$ & $\begin{array}{c}4 \\
(10.5)\end{array}$ \\
\hline Total & 400 & 248 & $\begin{array}{c}76 \\
(30.6) \\
\end{array}$ & $\begin{array}{c}106 \\
(42.7)\end{array}$ & $\begin{array}{c}20 \\
(\mathbf{8 . 0})\end{array}$ & $\begin{array}{c}22 \\
(8.8) \\
\end{array}$ & $\begin{array}{c}12 \\
(4.8) \\
\end{array}$ & $\begin{array}{c}6 \\
(2.4) \\
\end{array}$ & $\begin{array}{c}6 \\
(2.4) \\
\end{array}$ \\
\hline
\end{tabular}

bacterial agents. Isolation of bacterial agents from electronic devices such as handheld computers and personal digital assistants has shown these devices to be possible modes of transmission of nosocomial pathogens [9]. In a study conducted in Queen Elizabeth hospital in Barbados, West Indies, over $40 \%$ of mobile phones of 266 medical staff and students were culture positive [10]. Ulger et al. [11] reported that $94.5 \%$ of 200 health care workers and their mobile phones were contaminated with various microorganisms, including nosocomial pathogens, in a study conducted in New York and Israel. The present study concurs with their findings; thus contaminated, close-contact objects could serve as reservoirs of bacterial agents which could be easily transmitted from the mobile phones to the hands, and then from the hands to other areas of the body such as mouth, nose and ears.

Out of the four groups (A-D) studied, Group A had the highest rate of bacterial contamination (92;37\%), followed by Group B (72; 30.6\%), Group C $(42 ; 16.9 \%)$, and Group D $(38 ; 15.3 \%)$. The high prevalence of bacterial agents isolated from the mobile phones of Group A could be attributed to the poor hygienic and sanitary practices associated with the low level of education among marketers and food vendors, especially those involved in handling raw meats and vegetables, compared to individuals working in a hospital environment (Group D) where there is regular disinfection. Similarly, poor handling, among other factors, may account for high levels of bacterial pathogen contamination observed in the mobile phones of individuals from groups B and C. Coagulase negative Staphylococcus (CNS) was the most prevalent bacterial agent isolated from 106 $(42.7 \%)$ mobile phones in this study. This result corroborates the findings of Karabay et al. [6], in which CNS was the most frequently encountered bacterial agent isolated from $68.4 \%$ of the subjects evaluated. Brady et al. [3] had shown that the combination of constant handling and heat generated by the phones creates a prime breeding ground for microorganisms that are normally found in our skin. This may be because these types of bacteria increase in optimum temperature and phones are perfect for breeding these germs as they are kept warm and easy to handle in pockets, handbags and brief-cases.

In this study, other organisms isolated included $S$. aureus, $P$. aeruginosa and $K$. pneumoniae, E. coli, and Enterococcus faecalis. It is a well-established fact that these bacteria are agents of nosocomial infections. Rusin et al. [12] had documented both gram-positive and gram-negative bacteria in the hand-to-mouth transfer during casual activities. The present findings imply that mobile phones may serve 
Table 2. Antimicrobial susceptibility patterns of bacterial agents identified

\begin{tabular}{|c|c|c|c|c|c|c|c|c|c|c|c|c|c|c|}
\hline \multirow{2}{*}{ ORGANISM } & \multirow{2}{*}{$\begin{array}{l}\text { Number } \\
\text { isolated }\end{array}$} & AUG & $\mathrm{CRO}$ & GEN & NIT & COT & OFL & AMX & TET & PFX & CPX & CHL & ERY & STR \\
\hline & & $\mathrm{S}$ & $\mathrm{S}$ & $\bar{S}$ & $\mathrm{~S}$ & $\mathrm{~S}$ & $\mathrm{~S}$ & $\mathrm{~S}$ & $\mathrm{~S}$ & $S$ & $\mathrm{~S}$ & $\mathrm{~S}$ & $\mathrm{~S}$ & $S$ \\
\hline Escherichia coli & 22 & $\begin{array}{c}2 \\
(9.1)\end{array}$ & $\begin{array}{c}22 \\
(100)\end{array}$ & $\begin{array}{c}16 \\
(72.7)\end{array}$ & $\begin{array}{c}12 \\
(54.5)\end{array}$ & $\begin{array}{c}14 \\
(63.6)\end{array}$ & $\begin{array}{c}22 \\
(100\end{array}$ & $\begin{array}{c}- \\
(0)\end{array}$ & $\begin{array}{c}- \\
(0)\end{array}$ & $\begin{array}{c}22 \\
(100)\end{array}$ & $\begin{array}{c}20 \\
(90.9)\end{array}$ & $\begin{array}{c}2 \\
(9.1)\end{array}$ & $\begin{array}{c}6 \\
(27.8)\end{array}$ & $\begin{array}{c}4 \\
(18.2)\end{array}$ \\
\hline $\begin{array}{l}\text { Klebsiella } \\
\text { pneumoniae. }\end{array}$ & 12 & $\begin{array}{c}6 \\
(50) \\
\end{array}$ & $\begin{array}{c}12 \\
(100) \\
\end{array}$ & $\begin{array}{c}10 \\
(83.3) \\
\end{array}$ & $\begin{array}{c}- \\
(0) \\
\end{array}$ & $\begin{array}{c}- \\
(0)\end{array}$ & $\begin{array}{c}12 \\
(100)\end{array}$ & $\begin{array}{c}8 \\
(66.6) \\
\end{array}$ & $\begin{array}{l}- \\
(0)\end{array}$ & $\begin{array}{c}10 \\
(83.3) \\
\end{array}$ & $\begin{array}{c}8 \\
(66.6) \\
\end{array}$ & $\begin{array}{c}6 \\
(50) \\
\end{array}$ & $\begin{array}{c}4 \\
(33.6) \\
\end{array}$ & $\begin{array}{c}2 \\
(16.4) \\
\end{array}$ \\
\hline $\begin{array}{l}\text { Pseudomonas } \\
\text { aeruginosa }\end{array}$ & 6 & $\begin{array}{l}- \\
(0)\end{array}$ & $\begin{array}{c}6 \\
(100)\end{array}$ & $\begin{array}{c}- \\
(0)\end{array}$ & $\begin{array}{c}2 \\
(33.3) \\
\end{array}$ & $\begin{array}{c}4 \\
(66.6) \\
\end{array}$ & $\begin{array}{c}6 \\
(100)\end{array}$ & $\begin{array}{c}6 \\
(100)\end{array}$ & $(0)$ & $\begin{array}{c}6 \\
(100)\end{array}$ & $\begin{array}{c}6 \\
(100)\end{array}$ & $\begin{array}{c}2 \\
(33.3) \\
\end{array}$ & $\begin{array}{c}4 \\
(66.6) \\
\end{array}$ & $\begin{array}{c}2 \\
(33.3)\end{array}$ \\
\hline $\begin{array}{l}\text { Staphylococcus } \\
\text { aureus }\end{array}$ & 76 & $\begin{array}{c}16 \\
(22.6) \\
\end{array}$ & $\begin{array}{c}58 \\
(76.3) \\
\end{array}$ & $\begin{array}{c}36 \\
(47.3) \\
\end{array}$ & $\begin{array}{c}32 \\
(42.1) \\
\end{array}$ & $\begin{array}{c}20 \\
(26.3) \\
\end{array}$ & $\begin{array}{c}60 \\
(78.9) \\
\end{array}$ & $\begin{array}{c}40 \\
(52.6) \\
\end{array}$ & $\begin{array}{c}20 \\
(26.3) \\
\end{array}$ & $\begin{array}{c}62 \\
(81.5) \\
\end{array}$ & $\begin{array}{c}68 \\
(89.4) \\
\end{array}$ & $\begin{array}{c}32 \\
(42.1) \\
\end{array}$ & $\begin{array}{c}30 \\
(39.4) \\
\end{array}$ & $\begin{array}{c}50 \\
(65.7) \\
\end{array}$ \\
\hline $\begin{array}{l}\text { Coagulase } \\
\text { negative } \\
\text { Staphylococci }\end{array}$ & 106 & $\begin{array}{c}30 \\
(28.3)\end{array}$ & $\begin{array}{c}78 \\
(73.5)\end{array}$ & $\begin{array}{c}54 \\
(50.9)\end{array}$ & $\begin{array}{c}42 \\
(38.6)\end{array}$ & $\begin{array}{c}22 \\
(20.7)\end{array}$ & $\begin{array}{c}82 \\
(77.3)\end{array}$ & $\begin{array}{c}36 \\
(33.9)\end{array}$ & $\begin{array}{c}40 \\
(37.7)\end{array}$ & $\begin{array}{c}86 \\
(81.1)\end{array}$ & $\begin{array}{c}80 \\
(75.4)\end{array}$ & $\begin{array}{c}30 \\
(28.3)\end{array}$ & $\begin{array}{c}40 \\
(37.7)\end{array}$ & $\begin{array}{c}44 \\
(41.5)\end{array}$ \\
\hline $\begin{array}{l}\text { Enterococcus } \\
\text { feacalis }\end{array}$ & 20 & $\begin{array}{c}6 \\
(30)\end{array}$ & $\begin{array}{c}16 \\
(80)\end{array}$ & $\begin{array}{c}12 \\
(60)\end{array}$ & $\begin{array}{c}4 \\
(20)\end{array}$ & $\begin{array}{c}4 \\
(20)\end{array}$ & $\begin{array}{c}18 \\
(90)\end{array}$ & $\begin{array}{c}- \\
(0)\end{array}$ & $\begin{array}{c}6 \\
(30)\end{array}$ & $\begin{array}{c}18 \\
(90)\end{array}$ & $\begin{array}{c}16 \\
(80)\end{array}$ & $\begin{array}{c}6 \\
(30)\end{array}$ & $\begin{array}{c}10 \\
(50)\end{array}$ & $\begin{array}{c}10 \\
(50)\end{array}$ \\
\hline Bacillus spp. & 6 & $\begin{array}{c}2 \\
(33.3)\end{array}$ & $\begin{array}{c}4 \\
(66.6)\end{array}$ & $\begin{array}{c}- \\
(0)\end{array}$ & $\begin{array}{c}- \\
(0)\end{array}$ & $\begin{array}{c}6 \\
(100)\end{array}$ & $\begin{array}{c}2 \\
(33.3)\end{array}$ & $\begin{array}{c}- \\
(0)\end{array}$ & $\begin{array}{c}- \\
(0)\end{array}$ & $\begin{array}{c}- \\
(0)\end{array}$ & $\begin{array}{c}2 \\
(33.3)\end{array}$ & $\begin{array}{c}- \\
(0)\end{array}$ & $\begin{array}{c}- \\
(0)\end{array}$ & $\begin{array}{c}6 \\
(100)\end{array}$ \\
\hline Total & 248 & $\begin{array}{c}62 \\
(25.0)\end{array}$ & $\begin{array}{c}174 \\
(79.0)\end{array}$ & $\begin{array}{c}128 \\
(51.6)\end{array}$ & $\begin{array}{c}92 \\
(37.1)\end{array}$ & $\begin{array}{c}70 \\
(28.2)\end{array}$ & $\begin{array}{c}202 \\
(81.5)\end{array}$ & $\begin{array}{c}90 \\
(36.3)\end{array}$ & $\begin{array}{c}66 \\
(26.6)\end{array}$ & $\begin{array}{c}204 \\
(82.3)\end{array}$ & $\begin{array}{c}200 \\
(80.7)\end{array}$ & $\begin{array}{c}76 \\
(39.7) \\
\end{array}$ & $\begin{array}{c}88 \\
(35.5)\end{array}$ & $\begin{array}{c}118 \\
(47.6) \\
\end{array}$ \\
\hline \multicolumn{2}{|c|}{$\begin{array}{l}\text { AMX } \rightarrow \text { Amoxycillin, } \\
\text { STR } \rightarrow \text { Streptomycin, } \\
\text { CHL } \rightarrow \text { Chloraphenincol } \\
\text { AMX } \rightarrow \text { Amoxicillin }\end{array}$} & $\begin{array}{l}\mathrm{GEN} \rightarrow \mathrm{G} \\
\mathrm{ERY} \rightarrow \mathrm{E} \\
\mathrm{CRO} \rightarrow \mathrm{C}\end{array}$ & $\begin{array}{l}\text { ntamycin, } \\
\text { ythromycin } \\
\text { trriazone }\end{array}$ & & $\begin{array}{l}\rightarrow \text { Pefloxacin } \\
\rightarrow \text { Ofloxacin } \\
\rightarrow \text { Augmenti }\end{array}$ & & $\begin{array}{l}\text { XX Ciprof } \\
\text { DT } \rightarrow \text { Cotrim } \\
\text { IT } \rightarrow \text { Nitrofu }\end{array}$ & & & & & & & \\
\hline
\end{tabular}

as vehicles of transmission of diseases such as diarrhoea, pneumonia, boils, and abscesses.

Also, $P$. aeruginosa has been reported in the United States by the Centre for Disease Control and Prevention to be the most isolated nosocomial pathogen accounting for $10.1 \%$ of all hospitalacquired infections, and has been implicated in gastrointestinal infection, primarily in immunocompromised individuals [13]. It is interesting to note that there was no statistical significant difference $(\mathrm{p}>0.05)$ in the occurrence of $S$. aureus, the pathogenic bacterial agent most frequently isolated from the mobile phones of all the study groups, occurring in 32 (34.7\%), 18 (23.7\%), $12(28.8 \%)$ and $14(36.8 \%)$ of Groups A to D respectively (Table 1). The implication of this observation is that the possibility of being infected with bacterial pathogens simply by using other people's mobile phones is high.

Antimicrobial sensitivity testing revealed that over $75 \%$ of the isolates were susceptible to the fluoroquinolone and ceftriaxone antibiotics that were evaluated. Previous reports in Nigeria had shown that fluoroquinolones and third-generation cephalosporin are effective against a wide range of bacteria, and are expensive and less abused [14] than other antibiotics. Other antibiotics evaluated in this study ranged between 25.0 to $51.6 \%$ efficacy. However, the isolation of methicillin-resistant $S$. aureus strains from the mobile phones of health care workers had been documented [11]. Neither methicillin-resistant $S$. aureus strains nor strains of vancomycin resistant Enterococci were observed in this study.

Today's mobile phones are important devices for both the professional and social lives of their users. However, restrictions on the use of mobile phones by the Nigerian populace in certain areas of the environment where the percentage presence of bacteria is likely high (such as in hospitals, lecture theatres, animal slaughter areas, canteens, business centres, toilets and other such places) is difficult and thus not a practical solution. Users of mobile phone are hence advised to use antibacterial wipes to make their mobile phones germ free at all times. Also, strict adherence to infection control and precautions such as hand washing and good hygienic practice among the users of mobile phones is advocated, to prevent the possibility of phones as vehicles of transmission of both hospital and communityacquired bacterial diseases. 


\section{Acknowledgements}

The authors are grateful to members of the department of Microbiology, Health Centre, Lagos State University, and the student volunteers for their support and assistance.

\section{References}

1. Neubauer G, Röösli M, Feychting M, Hamnerius Y, Kheifets L, Kuster N, Ruiz I, Schüz J, Überbacher R., Wiart J (2005) Study on the Feasibility of Epidemiological. Studies on Health Effects of Mobile Telephone Base Stations - Final Report: A workshop Organized by Swiss Research Foundation on Mobile Communication Swiss Agency for the Environment, Forests and Landscape Swiss Federal Office of Public Health FSM - Project No. A20039.

2. Sowah LN (2008) The future of the Mobile Internet: How do we tap into its fullest benefits? Technology Blogs, 1-2.

3. Brady RR, Wasson A, Stirling I, McAllister C, Damani NN (2006).. Is your phone bugged? The incidence of bacteria known to cause nosocomial infection in healthcare workers mobile phones. J Hosp Infect 62: 123-125

4. Fleming K, Randle J (2006) Toys--friend or foe? A study of infection risk in a paediatric intensive care unit. Paediatr Nurs 18: 14-18.

5. Kosek M, Bern C, Guerrant RL(2003) The global burden of diarrhoeal disease, as estimated from studies published between 1992 and 2000. Bull World Health Organ. 81: 197-204.

6. Karabay O, Kocoglu E, Tahtaci M (2007) The role of mobile phone in the spread of bacteria associated with nosocomial infections. J. Infect. Develop. Countries. 1: 72-73.

7. Goldblatt JG, Krief I, Haller TD, Milloul V, Sixsmith DM, Srugo I, Potasman I (2007) Use of Cellular Telephones and Transmission of Pathogens by Medical Staff in New York and Israel. Infect Control Hosp Epidemiol 28: 500-503.

8. Bauer AW, Kirby WM, Sherris JC, Turck M (1966) Antibiotic susceptibility testing by a standardized single disk method. Am J Clin Pathol 45: 493-6.
9. Bures S, Fishbain JT, Uyehara CF, Parker JM, Berg BW (2000) Computer keyboards and faucet handles as reservoirs of nosocomial pathogens in the intensive care unit. Am J Infect Control 28: 465-471.

10. Ramesh J, Carter AO, Campbell MH, Gibbons N, Powlett C, Moseley H. Sr., Levis D, Carter T (2008) Use of mobile phones by medical staff at Queen Elizabeth Hospital Barbados: evidence for both benefit and harm. J Hospt Infect 70: 160-165.

11. Ulger F, Essen S, Dilek A, Yanik K, Gunaydin M, Leblebicioglu H (2009) Are we aware how contaminated our mobile phones are with nosocomial pathogens? Ann Clin Microbial Antimirob 8: 7.

12. Rusin P, Maxwell S, Gerba C (2002) Comparative surfaceto-hand fingertip to-mouth transfer efficiency of grampositive bacteria, gram negative bacteria and phage. J Appl Microbiol 93: 585-592.

13. Todar M (2004) Pseudomonas aeruginosa in Web Review of Todar's Online Textbook of Bacteriology "The Good, the Bad, and the Deadly" Science Magazine 304: 1-12.

14. Akinyemi KO, Bamiro BS, Coker AO (2007) Salmonellosis in Lagos Nigeria: Incidence of Plasmodium falciparum-associated Co-infection, Pattern of Antimicrobial Resistance, and Emergence of Reduced Susceptibility to Fluoroquinolones. J Health Popul Nur 25: 351-358.

\section{Corresponding Author}

Dr. K. O. Akinyemi

Department of Microbiology

Lagos State University

Ojo, PMB 1087, Apapa

Lagos, Nigeria

Email: akinyemiko@yahoo.com

Conflict of Interest: No conflict of interest is declared 